\title{
THE METHANOL SEED EXTRACT OF GARCINIA KOLA ATTENUATED ANGIOTENSIN II- AND LIPOPOLYSSACHARIDE-INDUCED VASCULAR SMOOTH MUSCLE CELL PROLIFERATION AND NITRIC OXIDE PRODUCTION
}

\author{
Adeolu A. Adedapo ${ }^{1}$, Temidayo O. Omobowale ${ }^{1}$, Ademola A. Oyagbemi ${ }^{1}$, \\ Momoh A. Yakubu ${ }^{2}$ \\ ${ }^{1}$ Faculty of Veterinary Medicine, University of Ibadan, Ibadan, Nigeria \\ ${ }^{2}$ Center of Cardiovascular Diseases, College of Pharmacy and Health Sciences, \\ Texas Southern University, Houston TX 77004
}

Received 12 January 2016; Received in revised form 15 March 2016; Accepted 21 March 2016

\begin{abstract}
All over the world, cardiovascular diseases are a risk factor for poor health and early death with predisposing factors to include age, gender, tobacco use, physical inactivity, excessive alcohol consumption, unhealthy diet, obesity, family history of cardiovascular disease, hypertension, diabetes mellitus, hyperlipidemia, psychosocial factors, poverty and low educational status, and air pollution. It is envisaged that herbal products that can stem this trend would be of great benefit. Garcinia kola (GK), also known as bitter kola is one of such plants. Generally used as a social snack and offered to guests in some cultural settings, bitter kola has been indicated in the treatment of laryngitis, general inflammation, bronchitis, viral infections and diabetes. In this study, the effects of methanol seed extract of Garcinia kola on the proliferation of Vascular Smooth Muscle Cells (VSMCs) in cell culture by Angiotensin II (Ang II) and LPS-induced NO production were carried out. Confluent VSMCs were exposed to GK $(25,50$ and $100 \mu \mathrm{g} / \mathrm{ml})$ before or after treatment with lipopolyssacharide $(100 \mu \mathrm{g} / \mathrm{ml})$, and Angiotensin II $\left(10^{-8}-10^{-6} \mathrm{M}\right)$. Cellular proliferation was determined by MTT assay and NO production by Griess assay. Treatment with Angiotensin II $\left(10^{-8}, 10^{-6}\right)$ or LPS significantly enhanced proliferation of VSM cells while LPS significantly increased nitric oxide (NO) production. Treatment with GK $(25,50 \& 100 \mu \mathrm{g} / \mathrm{ml})$ attenuated VSM cell proliferation. The results indicate that GK has potential to inhibit mitogen activated vascular cell growth and possibly inhibit inflammatory responses to LPS. Thus GK may be useful in condition that is characterized by cellular proliferation and inflammatory responses.
\end{abstract}

Key words: Garcinia kola, lipopolyssacharide, nitric oxide, angiotensin, VSMC

\section{INTRODUCTION}

Medicinal plants contain diverse phytotherapeutic classes of bioactive compounds such as polyphenols, tocopherols, alkaloids, etc. that hold promise as chemotherapeutic agents (12, 19). Studies have shown that flavonoids exhibit pharmacological activities, some of which include: vasoprotection, anti-carcinogenic, anti-microbial,

Corresponding author: Dr. Adeolu A. Adedapo, $\mathrm{PhD}$

E-mail address: aa.adedapo@maill.ui.edu.ng

Present address: Faculty of Veterinary Medicine, University of Ibadan,

Ibadan, Nigeria

Phone: +2348162746222

Copyright: (C) 2016 Adedapo A.A. This is an open-access article published under the terms of the Creative Commons Attribution License

which permits unrestricted use, distribution, and reproduction in any medium, provided the original author and source are credited. Competing Interests: The authors have declared that no competing interests exist.

Available Online First: 6 April 2016

Published on: 15 October 2016

http://dx.doi.org/10.1515/macvetrev-2016-0079 anti-inflammatory and anti-proliferative effects (12). These properties contribute to the health benefit effects of phytochemicals in herbal plants. The health benefit effects of flavonoids have been attributed to their ability to act as antioxidants, free radical scavengers and quencher of singlet and triplet oxygen, as well as inhibitors of peroxidation reactions (20).

Garcinia kola is known to be very rich in flavonoids $(1,24)$. Chemical analysis of the seed revealed the presence of Garcinia biflavanones (GB), xanthones, triterpenes and benzophenones (5, 17). The biflavanones are the most dominant in most Garcinia species (24). Kolaviron, an extract from G. kola and a biflavonoid, has also been shown to exhibit antioxidant activity (10). Kolaviron contains biflavonoids GB1, GB2, and kolaflavanone, and has been reported to significantly prevent drug-induced tissue damage in various experimental animal models (9). Bitter kola is eaten raw with folkloric 
belief that it promotes longevity. Extracts of the plant are used in traditional African medicine for the treatment of laryngitis, cough and liver diseases (15).

In the present study, we investigated the effects of GK on mitogen-induced vascular cell growth. We have evaluated the effects of GK extract on VSMC proliferation, mediated by mitogens such as angiotensin II (Ag II), LPS as well as the mediated regulation of ROS and NO.

\section{MATERIAL AND METHODS}

\section{Preparation of the methanol extracts of Garcinia kola seeds}

Garcinia kola seeds were purchased from a local market in Ibadan, Nigeria. The seeds were peeled, sliced, pulverized with an electric blender, and dried at $40^{\circ} \mathrm{C}$ in a Gallenkamp (London, UK) drying oven. The dried seeds were further pulverized with the electric blender and sieved with a fine sieve to give a uniform powder. A known gram $/ \mathrm{ml}$ of ethanol was subjected to continuous extraction using soxhlet. This extract was then concentrated with a rotary evaporator at $40-50^{\circ} \mathrm{C}$ under reduced pressure to obtain the methanol extract. The dried extract was then stored until it was needed for evaluation.

\section{Experimental design}

Cells were cultured to confluence, hypsinized and plated in 96 well plates for cell proliferation assay. Twenty four hours after plating, cells were treated with various concentrations $(25-100 \mu \mathrm{g} / \mathrm{ml})$ of the extract along with the control in the presence or absence of mitogens Ag II or LPS and cultured for 24-96 hours to determine effects of treatment on cell growth. MTT assay was performed at 24, 48, 72 and 96 hours. MTT assay is based on the ability of the cell to reduce MTT (3-(4, 5-Dimethylthiazol2-yl)-2, 5-diphenyltetrazolium bromide to purple formazan in the mitochondria of living cells. The viable VSM cells were seeded at a density of $5 \times 10^{4}$ (100 $\mu \mathrm{L} /$ well) in 96-well plates and incubated in a humidified atmosphere of $5 \% \mathrm{CO}_{2}$ and $95 \%$ air at $37^{\circ} \mathrm{C}$ for $24 \mathrm{~h}$ to form a cell monolayer. MTT assay was performed over three days. On day one, the VSM cells were trypsinized after these have confluence and on the second day the cells were treated with GK and the final volume of the media was adjusted to $100 \mu 1$ and the incubation continued. On day three $20 \mu \mathrm{l}$ of $5 \mathrm{mg} / \mathrm{ml}$ of MTT was added to each of the 96 wells, but the well used as controls had no cell. This was then incubated for three and half hours at $37^{\circ} \mathrm{C}$ in culture hood. After this, the 154 media was carefully removed and $150 \mu \mathrm{l}$ of MTT solvent was added and covered with tin foil and cells agitated on orbital shakers for 15 minutes. Thereafter, the absorbance was read at $590 \mathrm{~nm}$ (26). Griess assay was used to measure the Nitric oxide (NO) production according to the method of Olaleye et al. (22). $100 \mathrm{~mL}$ of sample were incubated with $100 \mathrm{~mL}$ of Griess reagent (Sigma) at room temperature for $20 \mathrm{~min}$. Nitrite level was determined by measuring the absorbance at $550 \mathrm{~nm}$ using a spectrophotometer.

\section{Statistics}

All values were expressed as mean \pm S.D. The test of significance between two groups was estimated by Student's t test. "One-way ANOVA with Dunnett's post-test was performed using GraphPad Prism version 4.00.

\section{RESULTS}

\section{Cell viability test}

The results of cell viability tests are as shown in Figures 1-6.

In Figure 1, the effects of GK on Ag II-induced (Ag $10^{-8}$ ) VSMC proliferation showed that 25, $50 \mu \mathrm{g} / \mathrm{ml}$ significantly attenuated cell proliferation, while the $100 \mu \mathrm{g} / \mathrm{ml}$ did not. Figure 2 showed the effect of GK on $\mathrm{Ag}$ II (Ag 10-8)-induced cell proliferation at 48 hours. While AG II treatment of VSMC increased cell proliferation compared to the control, this increased proliferation was attenuated by about $50 \%$ for $25 \mu \mathrm{g} / \mathrm{ml} \mathrm{GK}, 40 \%$ for 50 and $25 \%$ for $100 \mu \mathrm{g} / \mathrm{ml}$. These attenuations were significantly different from $\mathrm{Ag}$ II $\left(\mathrm{Ag} 10^{-8}\right)$ alone.

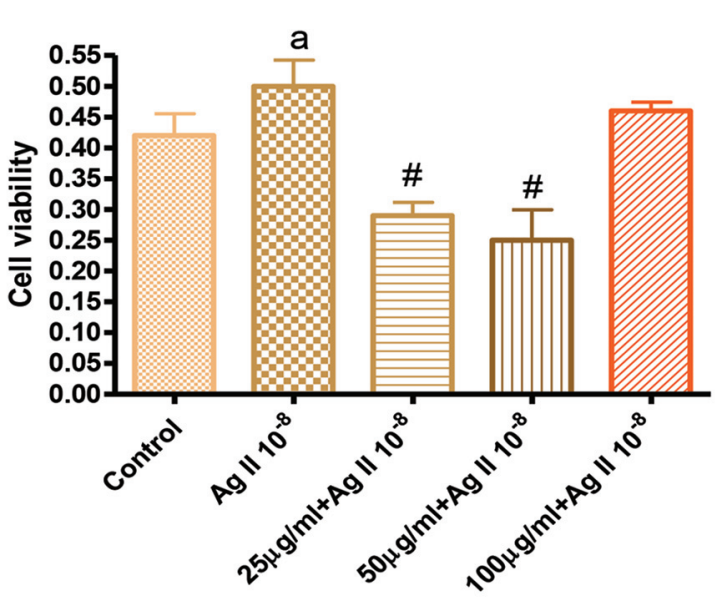

Figure 1. Effects of GK on Angiotensin $10^{-8}$ induced VSMC proliferation at 24 hours 


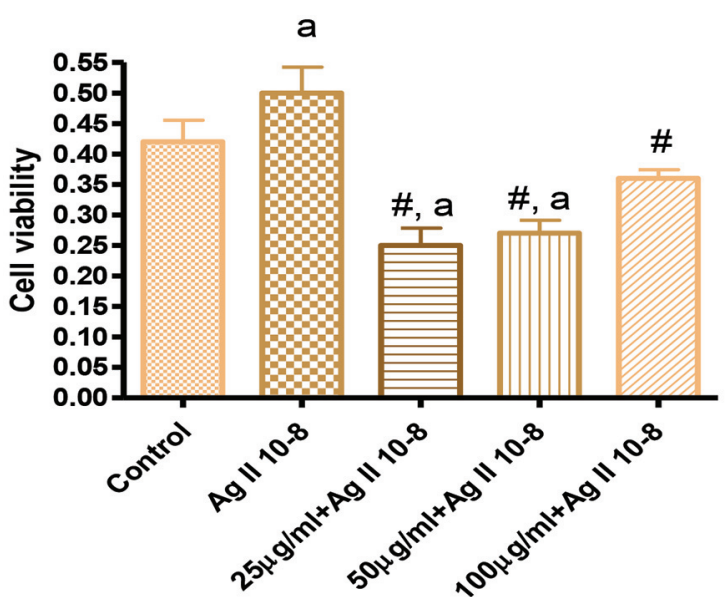

Figure 2. Effects of GK treatment on Angiotensin $10^{-8}$ induced cell proliferation at 48 hours

Figure 3 showed the effect of GK on Ag II $\left(\mathrm{Ag} 10^{-6}\right)$-induced increase cell proliferation at 48 hours. Ag II treatment of VSMC significantly increased cellular growth by $120 \%$ compared to the control. This increased proliferation was attenuated by treatment with GK $25-100 \mu \mathrm{g} / \mathrm{ml}$.

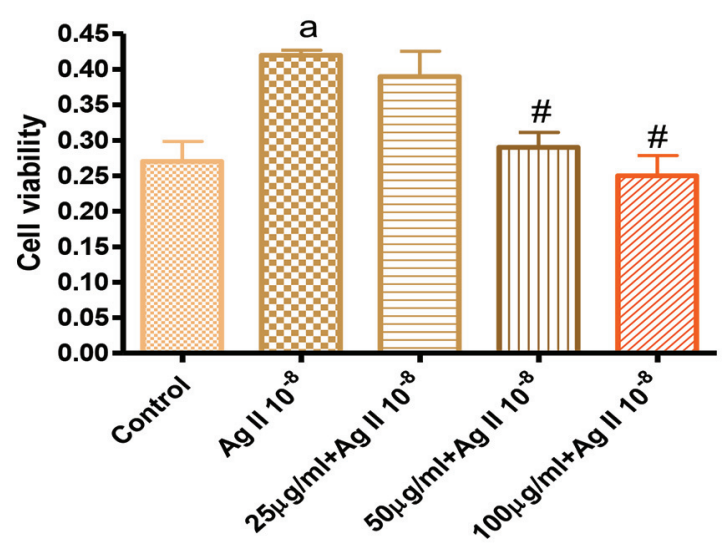

Figure 4. Effects of GK treatment on Angiotensin 10-8 induced cell proliferation at 72 hours

Figure 4 showed that treatment of VSMC with Ag II (Ag 10-8) significantly increased cell growth. However, treatment with GK $25 \mu \mathrm{g} / \mathrm{ml}$ had no effect on $\mathrm{Ag}$ II-induced cell proliferation, but GK at 50, $100 \mu \mathrm{g} / \mathrm{ml}$ significantly attenuated Ag II-induced cell proliferation.

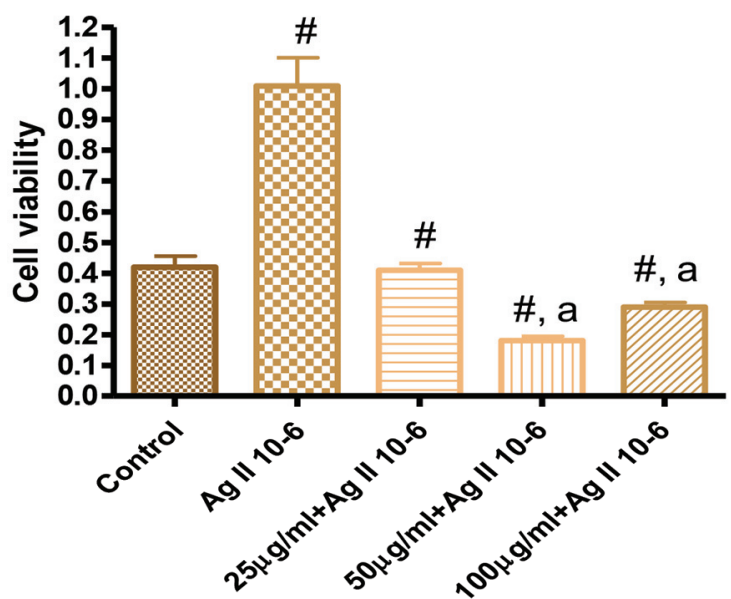

Figure 3. Effects of GK on Angiotensin $10^{-6}$ induced cell proliferation at 48 hours

Figure 5 showed that at 96 hours of growth, Ag II $\left(\right.$ Ag $\left.10^{-8}\right)$ significantly increased cell growth and this growth was significantly reduced in the presence of GK 50 and $100 \mu \mathrm{g} / \mathrm{ml}$, but not $25 \mu \mathrm{g} / \mathrm{ml}$. In figure 6, 96 hours after treatment with Ag II $\left(\mathrm{Ag} 10^{-6}\right)$, increased cell proliferation was observed, but treatment with GK at all concentrations significantly prevented the Ag II-mediated cell proliferation.

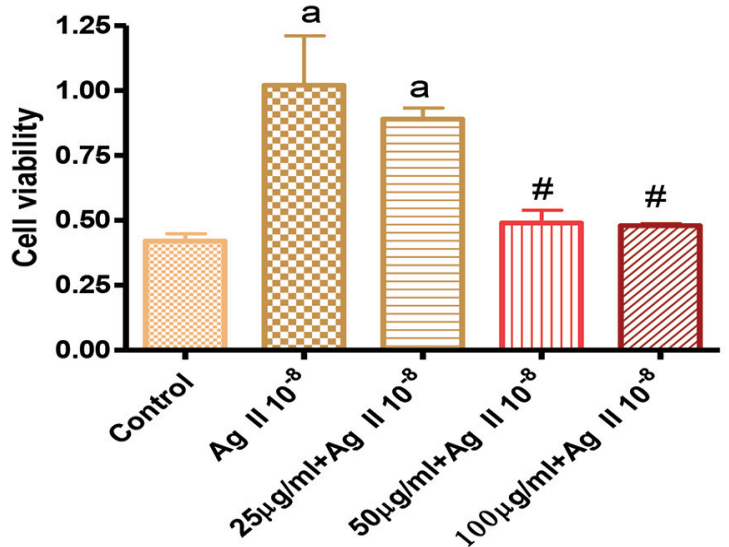

Figure 5. Effects of GK treatment on Angiotensin $10^{-8}$ induced cell proliferation at 96 hours

\section{LPS-induced ROS production}

Figure 7 showed that treatment of VSMC with LPS, a pro-oxidant agent significantly increased the production of reactive oxygen species (ROS). Co-treatment of cells with GK $(25-100 \mu \mathrm{g} / \mathrm{ml})$ significantly reduced the LPS-induced increase in ROS production. 


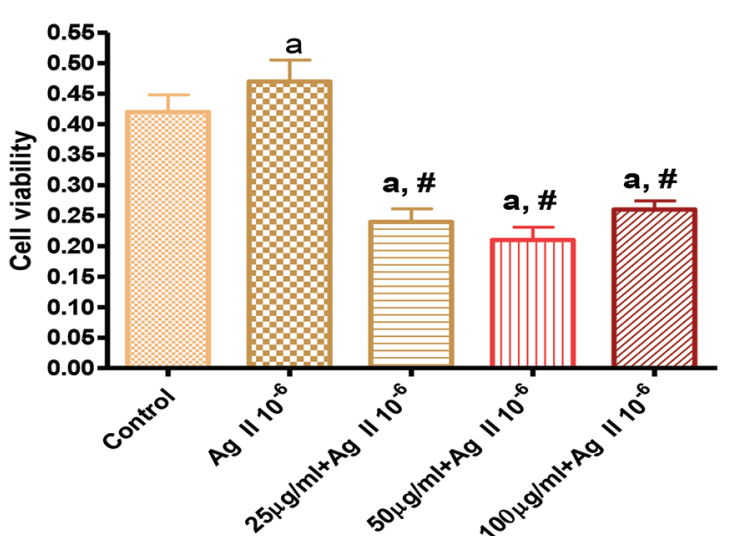

Figure 6. Effects of GK on Angiotensin 10-6 induced cell proliferation at 96 hours

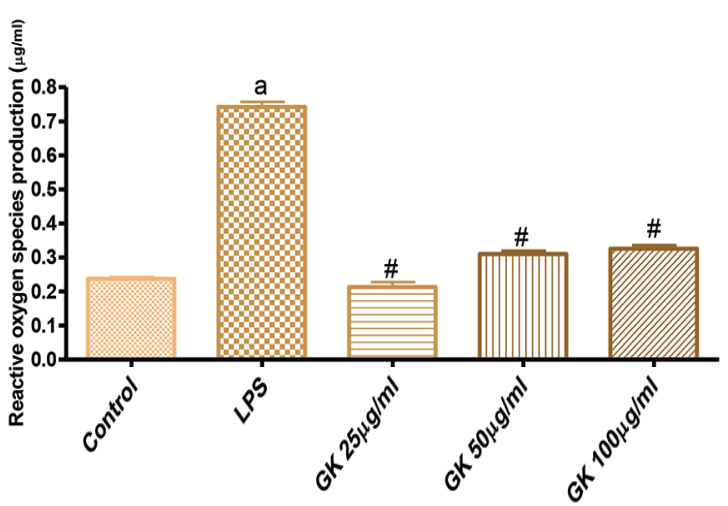

Figure 7. Effects of GK on Lipopolysaccharide (LPS)-induced reactive oxygen species (ROS) production

\section{LPS-induced nitric oxide production}

Figure 8 also showed the effects of treatment of cells with LPS on NO production. LPS moderately increased NO production and this production was attenuated and reversed to NO level comparable to the control following co-treatment with GK 25-100 $\mu \mathrm{g} / \mathrm{ml}$.

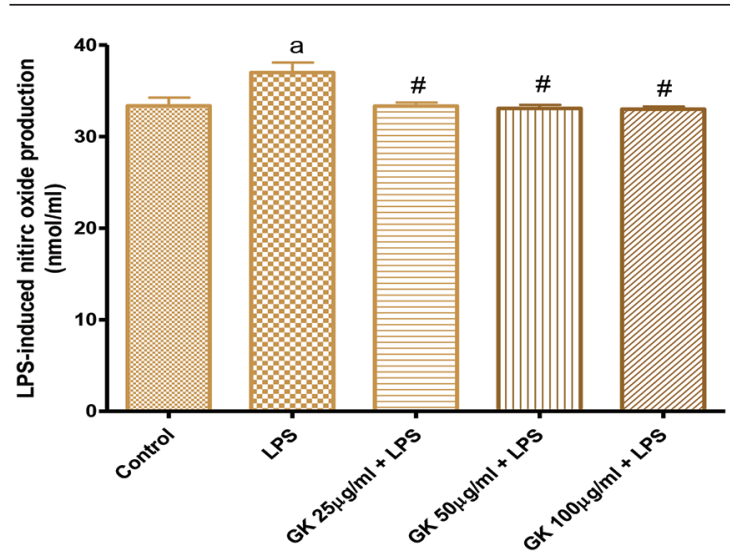

Figure 8. Effects of GK on Lipopolysaccharide (LPS)-induced nitric oxide production

\section{DISCUSSION}

In this study, the methanol extract of GK significantly inhibited VSMC growth. The extract also inhibited LPS and Angiotensin II-induced increased cell proliferations. LPS-induced increased production of ROS, as well as LPS-induced NO productions were also significantly attenuated by GK. The results indicate that GK may possess antiproliferative, antioxidant and possibly antiinflammatory properties. GK seed is known to be rich in some phytoactive substances such as 156 biflavonoids, xanthones, and benzophenones (17). These active ingredients in GK extract have antioxidant, anti-proliferative and anti-inflammatory properties (10). Vascular smooth muscle proliferation has been the hallmark of cardiovascular diseases especially in the development of hypertension, arteriosclerosis. Proliferation leads to intima formation in the vascular system $(4,7,21)$. In the present experiment, GK treatment prevented mitogen-induced VSMC proliferation because treatment of VSMC with GK significantly reduced cell proliferation. This effect was time-dependent, as the assay conducted after 96 hours incubation showed a higher inhibition of cell viability profile compared to the other incubation hours. Treatment of VSMC with angiotensin concentrations resulted in increased cell proliferation and this was inhibited by the extract at all the concentrations.

In this study, angiotensin was used as mitogen to promote cell proliferation. Garcinia kola was used to deter some of the effects on angiotensin II-induced proliferation. This result indicates that GK has antiproliferative properties as indicated by its reduction of angiotensin II-induced proliferation, suggesting the possibility of its use in cardiovascular diseases and this has been supported by several scientific reports $(2,8,9,11,15,16)$. Angiotensin II has been implicated in a series of disease conditions, especially cardiovascular diseases such as hypertension, stroke, and renal injury. The actions of angiotensin in the aetiology of these diseases are mediated via several pathways which involve generation of free radicals with its effects mediated by stimulation of smooth muscle cell growth, leading to intima formation which are commonly observed in hypertension cases $(3,13)$. Oxidative stress resulting from ROS has been associated with degenerative conditions such 
Garcinia kola attenuates vascular smooth muscle cell proliferation and nitric oxide production

as cardiovascular disease, cancer, weakening of immune system and aging (3). Epidemiological as well as experimental studies have shown that dietary flavonoids may protect against these diseases $(14,18)$. Most flavonoids exhibit a wide range of biological activities such as antibacterial, antiviral, anticarcinogenic, anti-inflammatory and antioxidant properties $(23,25)$.

Effect of GK on lipopolyssacharide (LPS)induced ROS generation was investigated following co-incubations of GK with LPS. The LPS-induced ROS generation was attenuated by the presence of GK. This result suggests that GK possessed an antioxidant property. LPS actions on biological systems are also mediated via induction of iNOS-production of NO, along with ROS generation. Also, treatment of cells with LPS along with GK resulted in inhibition of LPS-induced NO production. LPS mediates INOS expression through sequential activation of free radicals, protein kinase $\mathrm{C}(\mathrm{PKC})$ and protein tyrosine kinase (PTK) (6). PKC mediates essential cellular signals required for activation, proliferation, differentiation and survival and may be activated through a variety of agonists that may result in free radical generation (27). The GK extract significantly reduced ROS production indicating that the extract is a scavenger or prevents the activation pathway for the generation of ROS. Nitric oxide (NO), which is produced by nitric oxide synthases, plays a major role in a variety of mammalian biological processes including blood pressure homeostasis, immune regulation, and nervous system signal transmission. The concentration of NO determines whether NO acts as a beneficial signal molecule or when overproduced, acts to cause various stress symptoms due to the production of other nitric oxide species, especially peroxynitrite. In this study, LPS-induced nitric oxide production via activation of iNOS was inhibited by the extract indicating that GK can prevent the possible activation of iNOS along with ROS.

\section{CONCLUSION}

It could then be concluded from this study that GK may possess anti-inflammatory and anti-oxidant properties due in part to its ability to oppose LPS activities in terms of iNOS inhibition, PKC suppression as well as inhibition of COX-2 expression. The GK seed is eaten raw by humans with the folklore belief that it promotes longevity. The study may have supported this assertion of the seed promoting longevity.

\section{REFERENCES}

1. Adaramoye, O.A., Mederois, I.A. (2009). Endothelium-independent vasodilation induced by kolaviron, a biflavonoid complex from Garcinia kola seeds, in rat superior mesenteric arteries. Journal of Smooth Muscle Research 45 (1): 39-53. http://dx.doi.org/10.1540/jsmr.45.39 PMid:19377272

2. Adaramoye, O.A., Farombi, E.O., Adeyemi, E.O., Emerole, G.O. (2005). Inhibition of human low density lipoprotein oxidation by flavonoids of Garcinia kola seeds. Pakistan Journal of Medical Sciences 21, 331-339.

3. Brennan, L.A., Morris, G.M., Wasson, G.R., Hannigan, B.M., Barnet, Y.A. (2000). The effect of vitamin $\mathrm{C}$ or vitamin $\mathrm{E}$ supplementation on basal and $\mathrm{H}_{2} \mathrm{O}_{2}$-induced DNA damage in human lymphocytes. British Journal of Nutrition 84, 195-201. http://dx.doi.org/10.1017/S0007114500001422 PMid:11029970

4. Cobrinik, D. (2005). Pocket proteins and cell cycle control. Oncogene 24, 2796-2809. http://dx.doi.org/10.1038/sj.onc.1208619 PMid:15838516

5. Cotterhill, P.J., Scheinmann, F., Stenhouse, T.A. (1978). Extractives from Guttiferae: kolaflavanone, a new biflavanone from the nuts of Garcinia kola Heckel. Journal of Chemical Society Perkin Trans 1, 246-249.

6. Dauphinee, S.M., Karsan, A. (1984). Lipopolyssacharide signaling in endothelial cells. Laboratory Investigation 23, 5036-5039.

7. Dimova, D.K., Dyson, N.J. (2005). The E2F transcription network: old acquaintances with new faces. Oncogene 24, 2810-2826.

http://dx.doi.org/10.1038/sj.onc.1208612

PMid: 15838517

8. Farombi, E.O., Nwaokeafor, I.A. (2005). Antioxidant mechanisms of kolaviron: studies on serum lipoprotein oxidation, metal chelation and oxidative membrane damage in rats. Clinical and Experimental Pharmacology and Physiology 32, 667-674. http://dx.doi.org/10.1111/j.0305-1870.2005.04248.x PMid:16120195

9. Farombi, E.O., Shrotriya, S., Surh, Y.J. (2009). Kolaviron inhibits dimethyl nitrosamine-induced liver injury by suppressing COX-2 and iNOS expression via NF-KB and AP-1. Life Science 84, 149-155. http://dx.doi.org/10.1016/j.1fs.2008.11.012 PMid:19081081

10. Farombi, E.O., Akanni, O.O., Emerole, G.O. (2002). Antioxidative and scavenging activities of kolaviron in vitro. Pharmaceutical Biology 40, 107-116. http://dx.doi.org/10.1076/phbi.40.2.107.5838 
11. Farombi, E.O., Abarikwu, S.O., Adedara, I.A., Oyeyemi, M.O. (2007). Curcumin and kolaviron ameliorate di-n-butylphthalate-induced testicular damage in rats. Basic and Clinical Pharmacol and Toxicology 100, 43-48. http://dx.doi.org/10.1111/j.1742-7843.2007.00005.x PMid: 17214610

12. Ćetković, G.S., Djilas, S.M., Čanadanović-Brunet, J.M. Tumbas, V.T. (2004). Antioxidant properties of marigold extracts. Food Research International 37 , 643-650.

http://dx.doi.org/10.1016/j.foodres.2004.01.010

13. Guengerich, F.P., Ranar, G.N., Pernecky, S.J., Coon, M.J. (1997). Evidence for a role of perferryloxygen complex, $\mathrm{FeO}_{3}{ }^{+}$in the N-oxygenation of amines by cytochrome P450 enzymes. Molecular Pharmacology 51, 147-151.

PMid:9016357

14. Hertog, M.G.L., Feskens, E.J.M., Hollman, P.C.H., Katan, M.B., Kromhout, D. (1993). Dietary antioxidant flavonoids and risk of coronary heart disease. Lancet 342, 1007-1011. http://dx.doi.org/10.1016/0140-6736(93)92876-U

15. Iwu, M.M., Igboko, O.A. (1982). Flavonoids of Garcinia kola seeds. Journal of Natural Product 45, 650-665.

http://dx.doi.org/10.1021/np50023a026

16. Iwu, M.M. (1985). Antihepatotoxic constituents of Garcinia kola seeds. Experiential 41, 699-700. http://dx.doi.org/10.1007/BF02007729

17. Iwu, M.M. (1993). Handbook of African medicinal plants. Boca Raton, Florida, USA: CRC.

18. Keli, S.O., Hertog, M.G.L., Feskens, E.J.M., Kromhout, D. (1996). Dietary flavonoids, antioxidant vitamins and incidence of stroke. Archives of International Medicine 154, 637-642.

http://dx.doi.org/10.1001/archinte.1996.00440060059007

19. Lee, C.K., Park, K.K., Lim, S.S., Park, J.H., Chung, W.Y. (2007). Effects of the licorice extract against tumor growth and cisplatin-induced toxicity in a mouse xenograft model of colon cancer. Biological and Pharmaceutical Bulletin 30, 2191-2195.

http://dx.doi.org/10.1248/bpb.30.2191
20. Li-Chem, W., Hsiu-Wen, H., Yun-Chen, C., Chih-Chung, C., Yu-In, L., Ja-an, A.H. (2006). Antioxidant and antiproliferative activities of red pitaya. Food Chemistry 95, 319-327. http://dx.doi.org/10.1016/j.foodchem.2005.01.002

21. Meyer, D.L., Bahassi, E.M., Stambrook, P.J. (2005). The Plk3--Cdc25 circuit. Oncogene 24, 299-305. http://dx.doi.org/10.1038/sj.onc.1208278 PMid:15640846

22. Olaleye, S.B., Adaramoye, O.A., Erigbali, P.E., Adeniyi, O.S. (2007). Lead exposure increases oxidative stress in the gastric mucosa of $\mathrm{HCl} /$ ethanolexposed rats. World Journal of Gastroenterology 13(38): 5121-5126.

http://dx.doi.org/10.3748/wjg.v13.i38.5121

23. Torel, J., Cillard, J., Cillard, P. (1986). Antioxidant activity of flavonoid and reactivity with peroxyl radical. Phytochemistry 25, 383-385. http://dx.doi.org/10.1016/S0031-9422(00)85485-0

24. Waterman, P.G., Hussain, R.A. (1983). Systematic significance of xanthones, benzophenones and biflavonoids in Garcinia. Biochemical and Systemic Ecology 11, 21-30. http://dx.doi.org/10.1016/0305-1978(83)90025-X

25. Wattenberg, L.W. (1992). Inhibition of carcinogenesis by minor dietary constituents. Cancer Research 52, 2085S-2091S.

PMid: 1544145

26. van de Loosdrecht, A.A., Beelen, R.H., Ossenkoppele, G.J., Broekhoven, M.G., Lansenhuijsen, M.M. (1994). A tetrazolium-based colometric MTT assay to quantitate human monocyte mediated cytotoxicity against leukemic cells from cell lines and patients with acute myeloid leukemia. Journal of Immunological Methods 174, 311-320. http://dx.doi.org/10.1016/0022-1759(94)90034-5

27. Yakubu, M.A., Sofola, O.A., Igbo, I., Oyekan, A.O. (2004). Link between free radicals and protein kinase $\mathrm{C}$ in glucose-induced alteration of vascular dilation. Life Science 75 (24): 2921-2932. http://dx.doi.org/10.1016/j.1fs.2004.05.019 PMid:15454343 PMCid:PMC2922949 